REVISTA DE LITERATURA E CULTURA RUSSA

\title{
Nabokov, Dostoiévski e... Tolstói
}

\author{
Nabokov, Dostoevsky and... Tolstoy
}

Autora: Aurora Bernardini Universidade de São Paulo, São Paulo, São Paulo, Brasil

Edição: RUS Vol. 12. No 20

Publicação: Dezembro de 2021 DOI: https://doi.org/10.11606/issn.2317-4765.rus.2021.191736 


\section{Nabokov, Dostoiévski e... Tolstói}

\section{Aurora Bernardini*}

Resumo: Este ensaio comenta alguns aspectos da abordagem crítica de Nabokov de obras de Dostoiévski. Seus autores russos favoritos, sobre os quais escreveu trabalhos mais extensos, são Gógol, Tolstói e Tchekhov. Quanto a Dostoiévski (1821-1881) sua opinião é controversa, ora critica, ora aprecia suas obras.
Abstract: This article comments some aspects of Nabokovs's critical approach of Dostoevsky's works. Nabokovs's favorite Russian writers were Gogol, Tolstoy and Tchekhov, about them he wrote his most complet criticism. Nabokov's opinion on Dostoevsky is controversial: he both praises and criticizes his work.

Palavras-chave: Dostoiévski; Nabokov; Tolstói

Keywords: Dostoevsky; Nabokov; Tolstoy 
* Universidade de São Paulo, Programas de Pós-graduação em Letras Estrangeiras e Tradução (Russo) e Teoria Literária e Literatura Comparada da USP. Professora, tradutora, ensaísta e crítica literária; https://orcid. org/0000-0002-2559-7080; bernaur2@yahoo.com.br

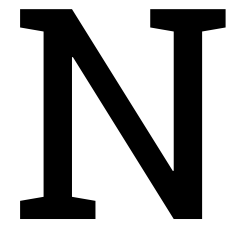

um programa televisivo de Artel que foi ao ar no dia 7 de agosto de 2021 sobre "Literatura Russa Contemporânea" foi apresentado um serviço da TV Britânica, com data de 2013, que implicava uma série de entrevistas com os principais autores dessa fase da literatura russa e com os seus leitores. $\mathrm{O}$ que me chamou muito a atenção foram as respostas destes últimos. A grande maioria deles, quando lhes perguntavam quais seriam seus autores russos mais lidos, respondiam sem hesitar: Vladímir Nabokov (1899-1977). E as Lições de Nabokov, sobre literatura russa e sobre literatura ocidental (preparado a partir de sua chegada aos EUA, em 1940) se haviam tornado, pelo visto, na Rússia, um guia de leituras para o século XXI. Segundo a introdução de Fredson Bowers à tradução brasileira de Jorio Dauster a Lições de Literatura Russa (Ed. Três estrelas), que vou utilizar aqui, essas notas (no total, quase duas mil páginas) iriam servir de referência para "os vinte períodos escolares" que durariam as aulas de Nabokov nas universidades americanas (Stanford, Wellesley e Cornell). Depois do sucesso mundial de Lolita, em 1958, Nabokov abandonou o magistério, mas as anotações foram conservadas em sua grande maioria (algumas, sobre autores russos menores, se perderam). As anotações sobre Dostoiévski, Tchekhov e Górki, preparadas por ele para o curso na Universidade de Cornell chamado "Literatura russa em tradução" foram publicadas na edição brasileira mencionada.

Para seus alunos americanos, Nabokov costumava apresentar um breve resumo biobibliográfico dos autores russos em questão, para depois passar a examinar aspectos "fundamentais" das obras por ele consideradas as mais significativas do escritor.

Seus autores russos favoritos, sobre os quais escreveu trabalhos mais extensos, são Gógol, Tolstói e Tchekhov. Quanto a 
Dostoiévski (1821-1881), sua opinião é controversa, ora aplaude, ora desanca suas obras. Vejamos alguns exemplos.

Em primeiro lugar, ele exalta a expressividade fonética e rítmica no livro de Dostoiévski que Nabokov considera a sua obra-prima: O duplo. Veja-se o comentário:

A melhor coisa que ele escreveu, na minha avaliação, foi O duplo, a história - contada de forma muito elaborada, com detalhes quase joycianos (tal como observou o crítico Mirski), e num estilo fortemente saturado de expressividade fonética e rítmica - de um funcionário do governo que enlouquece, obcecado pela ideia de que um colega usurpou sua identidade. É uma perfeita obra de arte, mas praticamente não existe para os seguidores de Dostoiévski, o Profeta, porque foi escrita na década de 1840, muito antes daqueles que são considerados seus grandes romances; ademais, sua imitação de Gógol é tão perfeita a ponto de parecer, por vezes, quase uma paródia. ${ }^{1}$

Em segundo lugar, Nabokov salienta o talento que Dostoiévski exibe como escritor de tramas de suspense, particularmente em seu livro de maior sucesso, segundo ele:

Os Irmãos Karamázov é o exemplo mais perfeito da técnica de história policial tal como empregada constantemente por Dostoiévski em seus outros romances. É um longo romance com mais de mil páginas e um romance curioso. São muitas coisas curiosas, até mesmo os títulos dos capítulos são curiosos. Vale notar que o autor não apenas está perfeitamente consciente da natureza excêntrica do livro, mas até parece querer a todo tempo chamar a atenção para isso, brincando com o leitor, usando vários recursos para lhe excitar a curiosidade" (p. 181).

Ao mesmo tempo, porém, em que louva a sua "história policial", não deixa de criticá-la. Para começar, castiga-lhe o que ele chama de "platitudes literárias", como o tema da "nobre prostituta, Sonia, no outro livro de Dostoiévski igualmente famoso, Crime e castigo:

Em Crime e castigo, Raskólnikov, por alguma razão, mata uma velha usurária e sua irmã. A justiça, na figura de um

1 NABOKOV, 2014, p. 149. 
inexorável policial, fecha lentamente o cerco em volta dele, até que, no final, Raskólnikov se vê forçado a fazer uma confissão pública, e graças ao amor de uma nobre prostituta, empreende uma regeneração espiritual que não parecia tão incrivel e banal em 1866, quando o romance foi escrito, como nos dias atuais, em que as prostitutas nobres tendem a ser recebidas com uma boa dose de cinismo pelos leitores experimentados. ${ }^{2}$

A mesma crítica é feita também à personagem Lisa, em $\mathrm{Me}$ mórias do subsolo (que ele insiste em chamar de "Memórias de debaixo do chão"):

Nosso homem do subsolo a fim de obter algum alívio como a ferir e assustar outra criatura humana, a pobre Lisa. As conversações são loquazes e bem medíocres, mas por favor, é necessário ir até o amargo fim (...) A história termina com nosso homem-rato expondo a ideia de que a humilhação e o insulto purificarão e elevarão Lisa em meio ao ódio e que talvez os sofrimentos extremos sejam melhores que a felicidade barata. Isso é praticamente tudo. ${ }^{3}$

Outro motivo de crítica é a valorização indevida do sofrimento e da humilhação por parte de Dostoiévski:

A convicção apaixonada de Dostoiévski de que o sofrimento físico e a humilhação aperfeiçoam a moralidade do homem pode derivar de uma tragédia pessoal: ele deve ter sentido que seu amor pela liberdade, sua rebeldia e seu individualismo sofreram uma perda ou, quando não, tiveram sua espontaneidade afetada durante o tempo que passou na prisão siberiana, mas ele se agarrou teimosamente à ideia de que voltara "um homem melhor."

O sofrimento físico e a humilhação são um dos meios de cativar os leitores por aquilo que Nabokov critica como sentimentalidade:

Cumpre distinguir "sentimental" e "sensível". O sentimentalista pode ser uma pessoa brutal, já alguém sensível nunca é cruel: uma senhora sentimental pode mimar seu papagaio e envenenar a sobrinha. O político sentimental pode se lem-

2 NABOKOV, 2014, p. 142.

3 NABOKOV, 2014, p. 173.

4 NABOKOV, 2014, p. 160. 
brar do dia das mães e desapiedadamente destruir um rival. ${ }^{5}$

Dostoiévski jamais superou a influência que os romances de mistério e histórias sentimentais europeias tiveram sobre ele. Os efeitos sentimentais implicavam um tipo de conflito muito a seu gosto - colocar pessoas virtuosas em situações patéticas - para extrair de tais situações a última gota de comoção. Após retornar da Sibéria, quando seus conceitos essenciais começaram a amadurecer - a ideia da salvação encontrada a partir da transgressão, a supremacia ética do sofrimento, em contraste com a luta e a resistência, a defesa do livre arbítrio, não como proposição metafisica e sim como proposição moral, e a fórmula derradeira de confrontar a Europa egoísta e anticristã com a Rússia da irmandade pró-cristã -, quando todas essas ideias impregnaram seus romances, muito da influência ocidental existia, a ponto de nos sentirmos tentados a afirmar que, de certo modo, e apesar de tanto odiar o Ocidente, Dostoiévski era o mais europeu dos escritores russos. ${ }^{6}$

Outra crítica de Nabokov é a falta de equilíbrio artístico:

$O$ assassino e a prostituta lendo o livro eterno - que bobagem! Não há vínculo retórico entre um vil assassino e essa moça infeliz. Apenas o vínculo convencional entre o romance de mistério com ecos góticos e as historietas sentimentais. Trata-se um truque literário barato, não de uma obra-prima de emoção e comiseração. Além do mais, vale notar a falta de equilíbrio artístico. O crime de Raskólnikov nos foi mostrado em todos os seus sórdidos pormenores, e também foram dadas algumas explicações diferentes para o feito do protagonista. Nunca, porém, vimos Sônia nos exercícios de sua profissão. A situação é um lugar comum pretencioso. $O$ pecado da prostituta não precisa ser discutido - e sustento que o verdadeiro artista nunca deixa de discutir algum assunto. ${ }^{7}$

Outro ponto levantado por Nabokov diz respeito à falha na caracterização dos protagonistas:

Dostoiévski, caracteriza seus personagens a partir de questões éticas, de reações psicológicas, de repercussões in-

5 NABOKOV, 2014, p. 148.

6 NABOKOV, 2014, p. 148.

7 NABOKOV, 2014, p. 157. 
ternas. Após descrever a aparência de um personagem, ele usa o velho recurso de não mais se referir a seus traços físicos. Segundo Tolstói, isso não é característico de um artista, que tem seu personagem em mente o tempo todo. E sabe exatamente que gesto específico ela fará neste ou naquele momento. $^{8}$

Fica claro aqui o modelo de escritor que Nabokov tem em mente: Lev Tolstói, que, em seu O Cânone Ocidental, seria considerado por ele "o maior prosador russo". É por seu método de caracterização, muito bem desenvolvido e exemplificado em Lições de literatura russa no capítulo dedicado a "Anna Kariênina", em que os detalhes são elevados à sua potência máxima, que ele julga Dostoiévski. O curioso é que esse caráter taxativo do juízo de Tolstói ("isso não é característico de um artista") marca também os juízos tolstoianos quanto à não artisticidade de Shakespeare em "Sobre Shakespeare e o drama”. Há, igualmente, uma visível subjetividade (rivalidade?) em relação ao próprio Dostoiévski, por parte de Tolstói:

- Seria bom ele conhecer o ensinamento de Confúcio ou dos budistas, isso o acalmaria. É o principal que todos e qualquer um deveriam conhecer. Ele era um homem de sangue quente; quando esbravejava, saíam calombos na sua careca, as orelhas moviam-se. Sentia muitas coisas, mas pensava mal, foi com os fourieristas que ele aprendeu a pensar, com Butachévitch e outros, depois os odiou a vida toda. ${ }^{9}$

Mas talvez o ponto central da crítica de Nabokov se prende à questão do "abuso" do cristianismo nas obras de Dostoiévski:

A falta de gosto de Dostoiévski, seu tratamento monótono de pessoas que sofriam de complexos pré-freudianos, o hábito de espojar nos trágicos infortúnios da dignidade humana - tudo isso é difícil de admirar. Não me agrada o truque se seus personagens de chegar a Jesus pela via do pecado. ${ }^{10}$

Isso é, em parte, assim justificado por Nabokov:

Em Recordaõoes da casa dos mortos (1862) (...) todas as humilhações e sevícias a que foi submetido são descritas em pormenores, assim como os criminosos entre os quais

8 NABOKOV, 2014, p. 150.

9 GÓRKI, 2006, p. 44.

10 NABOKOV, 2014, p. 149 
viveu. A fim de não enlouquecer de vez em tal meio, Dostoiévski precisava de alguma válvula de escape, que encontrou no cristianismo neurótico desenvolvido durante aqueles anos. É apenas natural que, entre os condenados com quem viveu, alguns demonstrassem um traço humano ocasional em meio à bestialidade pavorosa. Dostoiévski coletou tais manifestações e sobre elas construiu uma idealização muito artificial e completamente patológica do homem do povo na Rússia. Esse foi seu primeiro passo na estrada espiritual que passou a palmilhar. ${ }^{11}$

E, ainda:

Vou citar uma observação muito apropriada de Mirski sobre Dostoiévski: "Sua cristandade: é de um tipo muito duvidoso... trata-se de uma formação espiritual mais ou menos artificial que é um perigo identificar com a verdadeira cristandade", se a isso acrescentarmos que ele se arrogava a condição de genuíno interprete da cristandade ortodoxa e que, para desatar qualquer laço sociológico ou psicopático, invariavelmente nos conduzia a Cristo (ou à sua própria interpretação de Cristo e da sagrada Igreja Ortodoxa), compreenderemos melhor a faceta realmente irritante de Dostoiévski como filósofo. ${ }^{12}$

Sobre as doenças mentais que acometem os personagens de Dostoiévski, ${ }^{13}$ o elenco é extenso, aqui vão as principais: Epilepsia (Míchkin, Smerdiakóv, Kiríllov,Nelli); Demência senil (General Ivólguin); Histeria( Lisa Khokhlakova, Lisa Túchina, Nastássia Filipovna, Katerina); Psicopatia (Rogójin, Ivan Karamázov, Raskólnikov, Stavróguin) etc.

O que se nota, de uma maneira geral, é o mesmo que há em Tolstói: certa má vontade em relação a Dostoiévski, que - no caso de Nabókov - ele explica da seguinte maneira:

Minha posição em relação a Dostoiévski é curiosa e difícil. Em todos os meus cursos abordo a literatura a partir do único ponto de vista que me interessa - a saber, o da arte duradoura e do talento individual. Dessa perspectiva, Dos-

11 NABOKOV, 2014, p. 145.

12 NABOKOV, 2014, p. 175.

13 De acordo com Nabokov, as categorias de doença mental que ele atribui aos personagens de Dostoiévski foram extraídas de Stephenson Smith, S.; Isotoff Andrei. The Abnormal form within Dostoievsky in The Psycoanalytic Review, XXII, out./1919, pp. 361-91. 
toiévski não é um grande escritor, ao contrário, é bastante medíocre - com lampejos de excelente humor, mas, infelizmente, separados por oceanos de platitudes literárias. ${ }^{14}$

Por outras perspectivas que o leitor terá o prazer de percorrer, porém, reconhece-lhe o mérito de saber admiravelmente reunir farsa e tragédia e (o que não poderia faltar), de ser um dramaturgo manqué:

Mas há algo ainda mais notável sobre Dostoiévski. Ele pareceria ter sido escolhido pelo destino para ser o maior dramaturgo russo, porém tomou o rumo errado e escreveu romances. Os irmãos Karamázov sempre pareceu uma peça mal sistematizada, contendo apenas aqueles móveis e outros recursos indispensáveis aos vários atores: uma mesa redonda com a marca circular e molhada de um copo, uma janela pintada de amarelo para dar a impressão de que fazia sol lá fora, ou um arbusto trazido às pressas por um assistente do teatro e posto no palco de qualquer maneira. ${ }^{15}$

O curioso, mais uma vez, é notar que Lev Tolstói em seu ensaio "Sobre Shakespeare e o drama" dizia a mesma coisa de William Shakespeare...

\section{Referências bibliográficas}

BLOOM, Harold. O cânone ocidental. Rio de Janeiro: Objetiva, 2001.

GÓRKI, Máximo. Três russos. São Paulo: Martins Fontes, 2006.

NABOKOV, Vladimir. Lições de literatura russa. São Paulo: Três Estrelas, 2014.

TOLSTÓI, Lev. "Sobre Shakespeare e o drama" (original russo disponível em: https://rvb.ru/tolstoy/01text/vol_15/ 01text/0332.htm)

Recebido em: 24/10/2021

Aceito em: $30 / 11 / 2021$

14 NABOKOV, 2014, p. 142.

15 NABOKOV, 2014, p. 150. 